\title{
The configuration of the Brazilian scientific field
}

\author{
RITA B. BARATA ${ }^{1}$, ERIKA ARAGÃ ${ }^{2}$, LUIS E.P. FERNANDES DE SOUSA ${ }^{2}$, \\ TARIS M. SANTANA ${ }^{2}$ and MAURICIO L. BARRETO ${ }^{2}$ \\ ${ }^{1}$ Faculdade de Ciências Médicas Santa Casa de São Paulo/ FCMSCSP, \\ Departamento de Medicina Social, Rua Dr. Cesário Mota Jr, 60, 01221-020 São Paulo, SP, Brasil \\ ${ }^{2}$ Universidade Federal da Bahia/ UFBA, Instituto de Saúde Coletiva, \\ Rua Basílio da Gama, s/n, Campus Universitário do Canela, 40111-040 Salvador, BA, Brasil
}

Manuscript received on January 22, 2013; accepted for publication on June 12, 2013

\begin{abstract}
This article describes the configuration of the scientific field in Brazil, characterizing the scientific communities in every major area of knowledge in terms of installed capacity, ability to train new researchers, and capacity for academic production. Empirical data from several sources of information are used to characterize the different communities. Articulating the theoretical contributions of Pierre Bourdieu, Ludwik Fleck, and Thomas Kuhn, the following types of capital are analyzed for each community: social capital (scientific prestige), symbolic capital (dominant paradigm), political capital (leadership in S \& T policy), and economic capital (resources). Scientific prestige is analyzed by taking into account the volume of production, activity index, citations, and other indicators. To characterize symbolic capital, the dominant paradigms that distinguish the natural sciences, the humanities, applied sciences, and technology development are analyzed theoretically. Political capital is measured by presidency in one of the main agencies in the S \& T national system, and research resources and fellowships define the economic capital. The article discusses the composition of these different types of capital and their correspondence to structural capacities in various communities with the aim of describing the configuration of the Brazilian scientific field.
\end{abstract}

Key words: scientific community, scientific field, Brazilian science, scientific capital.

\section{INTRODUCTION}

The growth of graduate programs and the promotion of research and scientific production in Brazil in the last decade have drawn the attention of the scientific community worldwide (King 2009, Regalado 2010). However, in addition to its growth in absolute terms, knowledge of how the Brazilian scientific field is configured is important for the country's development. Thus, several relevant questions must be answered. Do the different communities of scientists contribute equally to this growth? Are there some communities

Correspondence to: Rita Barradas Barata

E-mail: rita.barradasbarata@gmail.com that stand out? How is growth distributed? Are these communities equivalent in structural terms and the volume and composition of their political, social, symbolic and economic capital?

\section{THE CONCEPTS OF SCIENTIFIC FIELD AND Habitus}

The social world can be described as a space that is constituted by social relationships and differentiation processes among agents that occupy distinct positions in this space and built on principles of the distribution of various types of capital - economic, cultural, social, and political. The social world can also be considered as a field 
of forces imposed on all who compose it without such forces being reduced to the intentions of any agent (Bourdieu 1989).

Any social area can be described as a multidimensional space that is defined by a set of relevant factors, according to which agents are distributed into different dimensions that constitute relational or cluster classes. The structure produced by the configuration of these different positions is transformed, in the symbolic dimension, into different levels, orders, grades, or hierarchies. Thus, objective power relationships tend to be reproduced in the symbolic strength relationships and the worldviews of different social groups, thereby maintaining this set of relationships (Bourdieu 1989).

Habitus is knowledge acquired in the process of socialization, entry, and residence in each field. It serves as a disposition (in the strong sense of the term) that is incorporated into the agent. It confers the agent a practical sense rather than a rational ability to move within the area and to relate with other participants (Bourdieu 1989, 2001).

In distinguishing itself, society produces, among other things, differentiation in modes of knowledge by instituting specific fields that are related to common sense and religious, aesthetic, philosophical, and scientific knowledge.

The scientific field can be considered as a microcosm of society. It is identical to other social fields in the sense of having concentrations of power and capital, monopolies, power relationships, conflicts, and interests, but it also requires reason. That is, it is a field in which practical sense does not serve in guiding the action of agents, all those involved in producing knowledge (Bourdieu 2001, Almeida Filho 2011).

The scientific field is distinguished from other fields by the orderly and organized form of competition, logical and experimental constraints to which it is subjected, and the purposes of knowledge that are sought. Every scientific proposition about the material world is a construction that seeks to be affirmed in this field against all other propositions.
However, conflicts occur under the control of the field's rules and generally only take advantage of authorized "weapons".

The scientific field is crossed by competition between different conceptions or views of the world that are each derived and compatible with methodical demands. Thus, these different views and the practices that they generate are immeasurable, thereby conferring an unstable and heterogeneous structure to the field (Kuhn 1989).

Science is conducted by communities of researchers that form different "thought collectives" (Fleck 1986). A thought collective exists when people who are involved in solving certain problems exchange ideas, thus constructing styles of knowledge that serve as a coercion in the sense of determining the type of preparation and intellectual orientation available to observe and act in a certain way while excluding other possibilities for action.

Historically, communities of scientists progressively built a separation between popular knowledge and specialized knowledge. In this process of ongoing development of the scientific field, particular spheres or communities of specialists were formed within the circle of specialized knowledge, at first around different disciplines and then around specific issues (Fleck 1986).

The concept of thought style elaborated by Fleck bears a great resemblance to the concept of paradigm, a central idea in the work of Thomas Kuhn (1989). However, whereas the Kuhnian paradigm relates almost exclusively to theoretical and methodological agreements established within the community of scientists, the thinking style specific to a certain collective of researchers extends beyond agreements and conventions of the discipline. It includes other aspects of social relationships between scientists, which Fleck considered as determinants of both preparation and intellectual availability of the members in each thought collective.

Paradigms are shared by practitioners in a scientific community as a disciplinary or 
thematic matrix composed of several types of elements, such as symbolic generalizations (laws and definitions); collective commitments with beliefs in certain models that provide the group with accepted analogies and metaphors; and shared values and exemplary solutions that serve as the basis for addressing new problems. The paradigms also serve as the basis for addressing relevant scientific questions or problems in the community and strictly relate to the dominant worldview in this collective (Kuhn 1989, Almeida Filho 2011).

The scientific communities show particular characteristics as a result of the peculiarities of the training necessary to become an accepted member in the community and the relative effect of social insulation that scientific practice causes. Scientists are typically engaged in the study of very specific problems whose solutions must be shared with colleagues who know the rules and the judging criteria. However, many individuals who do not belong to the community must also accept the solutions (Kuhn 1989).

We believe that the Brazilian scientific field is constituted by different scientific communities that carry a scientific habitus responsible for differentiation between these collectives and other forms of social organization. Each of these communities differs from the other communities due to the paradigms shared within the community and the thinking styles that define these collectives.

The distinction drawn by the intrinsic characteristics of these collectives of scientists overlaps other forms of distinction that result from the relative position of each community within the scientific field and the relationships established between them and other social groups. These distinctions generate greater or lesser possession of symbolic, cultural, social, economic, and political capital.

The purpose of this article is to map the Brazilian scientific field, characterizing the different communities in the main areas of knowledge.

\section{MATERIALS AND METHODS}

Each scientific community was characterized in terms of installed capacity, ability to train new researchers, and production of scientific articles. The distribution of power between the scientific communities will be presented based on indicators of scientific prestige (social capital), social prestige (symbolic capital), political power (political capital) and economic resources (economic capital).

The map of the Brazilian scientific field was constructed from secondary databases. The selected variables were grouped into the following three structural axes for each community: installed capacity (number of research groups, density, number of doctorates, number of institutions working in this area); training of new researchers (graduate programs with $\mathrm{PhD}$ programs, faculty members holding doctoral degrees, number of completed graduate supervision per faculty member); and scientific production (articles published in Portuguese, articles published in a foreign language, total number of articles, ratio of articles published in a foreign language and in Portuguese, articles in the Scopus database). This set of variables was used to characterize the composition of the scientific field in the main areas of knowledge.

In addition to the structural axes, the following variables were used to characterize various types of capital for each scientific community: measures of prestige; financial resources for development, paradigms; and leadership positions in scientific policy or training.

Citation indicators and participation in global production and international cooperation $(\mathrm{H}$ index and citations per document published, $\%$ of citations in journals from their own country, contribution of Brazilian production to global production, $\%$ of articles with international collaboration) were employed as measures of prestige or social power. The activity index for each community was 
calculated as the ratio of the area's proportion of national production to the same area's proportion of global production. The rate of relative citations was calculated using the following formula: 1- (citations/ doc for the area in national production - citations/ doc for the area in global production)/citations/doc for the area in terms of global production.

As indicators of symbolic capital in each major area, the general paradigms that guide the production of knowledge were considered, i.e., the tradition that is affiliated with the scientific world in all of the major areas, paradigm of natural sciences, paradigm of cultural sciences, paradigm of strategic research or technological paradigm, and the social perception of these paradigms.

Political capital was indirectly assessed by the occupation of positions in scientific policy. The durations of presidential mandates were considered for the Conselho Nacional de Desenvolvimento Científico e Tecnológico - CNPq, Coordenação de Aperfeiçoamento de Pessoal de Nível Superior - CAPES, Financiadora de Estudos e Projetos FINEP, Sociedade Brasileira para o Progresso da Ciência - SBPC, and Academia Brasileira de Ciência - ABC throughout the history of each agency according to the president's area of training.

To measure each area's economic power, the amount of funding obtained from the $\mathrm{CNPq}$ and the relationship between productivity grants and permanent faculty members in graduate programs were analyzed. Funding from the FINEP for R \& D was measured as the amount of resources allocated to each contracted project. Funding from the Departamento de Ciência, Tecnologia e Inovação - DECIT of the Ministry of Health (only for health research) was measured as the value of funded projects, excluding those for which the resource was transferred to the CNPq.

The census of research groups registered in the CNPq Directory of Research Groups was used to identify the number of groups and institutions, the proportion of doctors among researchers in each group, and the production of articles in Portuguese or a foreign language in each major area of knowledge.

Statistics from the CNPq were used to record the amount of financial resources spent on grants and support for projects in each major area of knowledge.

The productivity grants with active scholarships from the $\mathrm{CNPq}$ were used to characterize the relative distribution of teachers of graduate programs in every major area of knowledge.

The number of PhD holders, the number of graduate programs with a $\mathrm{PhD}$ program, and the number of faculty members holding a $\mathrm{PhD}$ in each area of knowledge were obtained from the CAPES database.

Information on the scientific production and prestige of each area of knowledge was obtained from the SJR SCImago database, with the selection criteria of articles from Brazilian authors published between 1996 and 2010. In addition to the number of articles published, the $\mathrm{H}$ index, the number of citations per document published, the rate of national citation, the proportion of Brazilian contribution to global production (sharing), and the proportion of articles in collaboration with authors from other countries were obtained.

Education and research institutions provide both the data from the Directory of Research Groups and the CAPES database with no verification mechanisms available. The financial data and the productivity grants are official data that are available to the public on the CNPq website.

The SCImago database represents only a portion of Brazilian scientific production, i.e., articles published in journals indexed by Scopus that have greater visibility and potential for international dissemination of Brazilian science. The database does not include production in journals indexed exclusively in other bibliographic databases or from Brazilians working in foreign institutions, thus reflecting production in Brazilian 
institutions rather than the production of Brazilian scientists. The overlap of journals indexed in major bibliographic databases is a large indication that the use of a broader bibliographic database, such as Scopus, likely allows a satisfactory characterization of scientific communities that share a tradition of publication in indexed journals.

However, for some areas of knowledge, the Brazilian scientific community does not direct a significant portion of production to indexed journals. Therefore, to better characterize these collectives, the number of articles published in national and foreign journals (available from the $\mathrm{CNPq}$ Directory of Research Groups) for each area was also identified.

Data from the FINEP were obtained on the website from the list of contracted projects. The amounts allocated to projects from the SBPC or universities' general research infrastructure were not included because these resources were not intended for a particular community.

Data from the DECIT were obtained from the Health Research information system by using the appropriate filters.

For the purpose of grouping and identifying the main areas of knowledge, the following classification criteria adopted by CAPES to organize graduate programs was utilized: Agricultural Sciences (agriculture, food science, veterinary medicine, and animal science); Biological Sciences (biological sciences and biodiversity); Health Sciences (medicine, public health, nursing, dentistry, pharmacy, physical education, physical therapy, speech therapy, and occupational therapy); Earth and Exact Sciences (mathematics, computer sciences, astronomy and physics, chemistry, and geology); Social Sciences (anthropology, political science, education, philosophy, geography, history, psychology, sociology, and theology); Applied Social Sciences (management, architecture and design, communications and information sciences, law, economics, urban planning and demography, and social services); Engineering; Arts, Literature, and Linguistics.
Data analysis was conducted considering the national value for each variable as a reference (1.00) and calculating the relative position for each major area of knowledge in each variable considered. To calculate the value corresponding to each axis, installed capacity, training, and production, the corresponding points were added to these relative positions. Thus, it was possible to reduce the set of data to three values that correspond to each of the structural axes for each major area.

\section{RESULTS}

StruCtural COMPONENTS OF THE SCIENTIFIC COMMUNITIES

\section{Installed capacity}

The development of infrastructure or installed capacity for research in Brazil formally began in the 1950s with the creation of major funding agencies and the formation of the CAPES. During the 1970s, another wave of support to scientific research occurred with the implementation of the National Fund for Scientific Development. In the 1990s, the creation of the Sectorial Funds at FINEP brough more financial resources to many areas of strategic research in the country. Finally, in the past decade scientific production had a remarkable impulse with a lot of official initiatives to improve graduate programs, access to scientific information and research funds.

The major areas of Biological Sciences, Agricultural Sciences, Health Sciences, and Earth and Exact Sciences had the largest number of research groups, the largest number of institutions, and the most doctors per group (Table I).

Glänzel et al. (2006) classified the profile of scientific production of countries using the following four models: the Western model, in which medical and biomedical sciences are predominant; the socialist model, in which exact sciences are predominant; the bio-environmental model, in which biological and earth sciences are predominant; and the Japanese model, in which engineering and chemistry are predominant. 
TABLE I

Installed capacity according to major areas of knowledge. Brazil 2006-2008.

\begin{tabular}{|c|c|c|c|c|c|c|}
\hline \multirow{2}{*}{ Major Area } & \multicolumn{2}{|c|}{ Institutions } & \multicolumn{2}{|c|}{ Research Groups } & \multicolumn{2}{|c|}{ Doctors } \\
\hline & No. & $\%$ & No. & $\%$ & No. & $\%$ \\
\hline Biological S. & 224 & 53.1 & 2,696 & 11.8 & 10,769 & 16.1 \\
\hline Agricultural S. & 181 & 42.9 & 2,177 & 9.5 & 9,378 & 14.0 \\
\hline Health S. & 250 & 59.2 & 3,961 & 17.4 & 13,164 & 19.7 \\
\hline Earth and Exact $\mathrm{S}$. & 209 & 49.5 & 2,515 & 11.0 & 9,809 & 14.7 \\
\hline Engineering & 227 & 53.8 & 3,027 & 13.3 & 10,729 & 16.1 \\
\hline Social S. & 262 & 62.1 & 4,219 & 18.5 & 13,107 & 19.6 \\
\hline Applied Social S. & 260 & 61.6 & 2,754 & 12.1 & 7,600 & 11.4 \\
\hline Arts, Literature, and Linguistics & 163 & 38.6 & 1,448 & 6.4 & 4,227 & 6.3 \\
\hline Total & 422 & 100.0 & 22,797 & 100.0 & 66,785 & 100.0 \\
\hline
\end{tabular}

Source: CNPq 2010. (Directory of Research Groups. 2010 Census).

The analysis of installed capacity indicated two particular characteristics: the presence of research groups in practically all fields of knowledge in most institutions, with the exception of the Arts, Literature, and Linguistics; and a mixed profile of scientific production that combines aspects of the Western and bio-environmental models.

This profile (i.e., different fields are equivalent or different scientific communities have similar installed capacities) likely reflects the low level of specialization in Brazilian universities, where scientific production is concentrated in the country (Leta et al. 2006). This characteristic can have negative repercussions for the productivity and visibility of these scientific communities (Leahey 2007).

\section{Training of researchers}

The area of Humanities and Social Sciences showed the greatest capacity for training new researchers due to the number of graduate study supervisions and graduate students earning degrees per faculty member, which exceeded expectations based on its installed capacity (Table II). That is, the numbers of doctors formed in these areas are proportionally greater than in other areas, considering the number of graduate programs and the supervisors that work on it. The areas of Health Sciences, Agricultural Sciences, Engineering, and Applied Social Sciences showed a training capacity that was compatible with their installed capacity. The areas of Biological Sciences and Earth and Exact Sciences showed training for new researchers below their installed capacity.

In Brazil, doctoral degrees increased by 3.8 times between 1990 and 2000 and 6.4 times between 2000 and 2009 (Hermes-Lima et al. 2008). In this component, there was a relative equilibrium between the scientific communities considered. However, some data call our attention, such as the low training capacity shown by Earth and Exact Sciences and the high training capacity in Humanities and Social Sciences.

Although the area of Earth and Exact Sciences had a significant number of doctoral programs, its overall productivity was comparatively low in terms of the number of advised students and graduates per supervisor. The greater productivity shown by the Humanities and Social Sciences reflects the greater number of faculty members and doctoral programs. In the Humanities and Social Sciences, there has been a major incentive for training doctorates since 1968, initially through grants for programs abroad and subsequently within the country. This policy has paved the way for the professionalization of a large number of faculty-researchers in all disciplines (Garcia Jr 2011).

\section{Academic Production}

The communities with the highest rates of articles per $\mathrm{PhD}$ researcher were in the Life Sciences: Health, Agricultural Sciences, and Biological 
TABLE II

Training of researchers according to major area of knowledge. Brazil 2007-2009.

\begin{tabular}{c|c|c|c|c|c}
\hline \multirow{2}{*}{ Major Area } & \multicolumn{2}{|c|}{ Doctoral Programs } & \multicolumn{2}{c|}{ Faculty Members } & \multicolumn{1}{c}{$\begin{array}{c}\text { Completed Supervision of } \\
\text { Graduate Study/ Faculty Member }\end{array}$} \\
\cline { 2 - 5 } & $\mathbf{N o .}$ & $\mathbf{\%}$ & $\mathbf{N o .}$ & $\mathbf{\%}$ & 0.8 \\
\hline Biological S. & 185 & 12.4 & 3,990 & 9.3 & 0.9 \\
\hline Agricultural S. & 205 & 13.8 & 4,578 & 10.7 & 0.7 \\
\hline Health S. & 312 & 21.0 & 8,049 & 18.8 & 0.6 \\
\hline Earth and Exact S. & 164 & 11.0 & 5,494 & 12.8 & 0.7 \\
\hline Engineering & 153 & 10.3 & 5,376 & 12.6 & 0.8 \\
\hline Social S. & 235 & 15.8 & 7,023 & 16.4 & 0.5 \\
\hline Applied Social S. & 141 & 9.5 & 5,301 & 12.4 & 0.7 \\
\hline Arts, Literature, and Linguistics & 93 & 6.3 & 2,950 & 6.9 & \\
\hline Total & $\mathbf{1 , 4 8 8}$ & $\mathbf{1 0 0 . 0}$ & $\mathbf{4 2 , 7 6 1}$ & $\mathbf{1 0 0 . 0}$ & $\mathbf{0 . 7}$ \\
\hline
\end{tabular}

Source: CAPES 2011a, b (Recommended Courses and Geocapes - Statistical Data).

Sciences, as these communities were above the national rates. The Earth and Exact Sciences evidenced a value that was slightly below the national average. Both Engineering and Humanities showed a fewer number of articles. These profiles may reflect the different traditions or processes of scientific work in these scientific communities (Table III).

Although some of the production in the Humanities and Social Sciences and the area of Arts, Literature, and Linguistics did not appear in journals indexed in the Scopus database, the data obtained from the CNPq database showed the same pattern of a fewer number of articles per doctor in these fields.
Etxebarria and Gomez-Uranga (2010) stated that $17 \%$ of journals indexed in the Scopus database are from the field of Humanities and Social Sciences, but only $2 \%$ of documents indexed belong to these areas of knowledge. After analyzing scientific production in Social Sciences in major Spanish universities, the authors found two profiles. Some researchers directed their production toward indexed journals, such as researchers in the natural sciences, but they had a fewer number of articles and citations. Other researchers published articles almost exclusively in Spanish and in non-indexed journals, books, and dissertations.

Between 1989 and 2007, the number of Brazilian articles indexed in the Thomson Reuters

TABLE III

Article production per doctor according to major areas of knowledge. Brazil 2006-2008.

\begin{tabular}{c|c|c|c|c|c}
\hline Major Area & $\begin{array}{c}\text { Articles in } \\
\text { Portuguese (1) }\end{array}$ & $\begin{array}{c}\text { Articles in Other } \\
\text { Languages (2) }\end{array}$ & $\begin{array}{c}\text { Total } \\
\text { Articles }\end{array}$ & $\begin{array}{c}\text { Ratio } \\
\mathbf{( 2 ) / ( 1 )}\end{array}$ & $\begin{array}{c}\text { Scopus Articles*/ } \\
\text { Faculty Member }\end{array}$ \\
\hline Biological S. & 0.8 & 1.7 & 2.6 & $2.1: 1$ & 8.7 \\
\hline Agricultural S. & 1.8 & 0.8 & 2.6 & $0.4: 1$ & 6.9 \\
\hline Health S. & 1.5 & 1.5 & 2.9 & $1.0: 1$ & 4.9 \\
\hline Earth and Exact S. & 0.5 & 1.6 & 2.1 & $3.2: 1$ & 6.5 \\
\hline Engineering & 0.5 & 0.8 & 1.3 & $1.6: 1$ & 0.5 \\
\hline Social S. & 1.0 & 0.2 & 1.2 & $0.2: 1$ & 2.8 \\
\hline Applied Social S. & 1.1 & 0.2 & 1.3 & $0.2: 1$ & 1.2 \\
\hline Arts, Literature, and Linguistics & 0.9 & 0.1 & 1.0 & $0.1: 1$ & 0.1 \\
\hline Total & $\mathbf{1 . 2}$ & $\mathbf{1 . 1}$ & $\mathbf{2 . 3}$ & $\mathbf{0 . 9 : 1}$ & $\mathbf{2 . 8}$
\end{tabular}

Source: CNPq 2010. (Directory of Research Groups, 2010 Census ); CAPES 2011b (Geocapes - Statistical Data); SCImago 2012 ( SJR - Journals \& Country Rank).

* Only in this column, the number of articles was obtained in SCImago 2012 (Scopus for the period 2007-2009). 
database increased by six times and the country's participation in global production increased from $0.56 \%$ to $2.02 \%$. In relative terms, the areas of knowledge with the greatest participation in global production between 2004 and 2008 in this database were Biological Sciences, Agricultural Sciences, and Earth and Exact Sciences (King 2009).

As regards the ratio of articles in Portuguese and articles in a foreign language, using the classification proposed by Leite et al. (2011), the only major area in which publication in a foreign language was predominant $(>60 \%$ in relation to the total publication) was Earth and Exact Sciences. For the areas of Biological Sciences, Health Sciences, and Engineering, the proportion of publications in foreign language was intermediate (40 to $60 \%$ ), and publication was primarily in Portuguese for the remaining areas.

A study conducted by Vasconcelos et al. 2005, with data from the Lattes platform, showed that only $33.8 \%$ of researchers included in research groups were considered proficient in English. Of the researchers that had articles in the Thomson Reuters database that year, 51\% rated their English skills as good. Compared to those who did not rate their English skills as good, this group produced a greater number of articles, greater number of citations, and achieved higher $\mathrm{H}$ index.

However, the issue of language does not determine the proportion of articles in Portuguese. For example, the target audience of applied or technological research may include professionals and decision-makers in addition to researchers in the same field. Scientific dissemination in their native language may facilitate the incorporation of research results into practice. Another aspect related to the proportion of articles in a foreign language is the gender composition of scientists in each community, as men publish 2.26 articles in a foreign language for each article published by a woman (Leite et al. 2011).

\section{SOCIAL, SYMBOLIC, POLITICAL, AND ECONOMIC CAPITAL}

Capital is a political concept that is defined as the accumulation of strength or ability to determine the course of events by agents within the field, where power games and relations occur (Bourdieu 1989).

\section{SOCIAL CAPITAL}

As a proxy for the social capital or scientific prestige of each community, we utilized the $\mathrm{H}$ index for the set of articles indexed in SJR, the citations received by documents published in the last two years (equivalent to the impact factor from the ISI-Web of Science), the proportion of national citations for articles, the area's proportional participation in global production, and the proportion of articles conducted in collaboration with foreign researchers. To evaluate the impact of national production given the different characteristics of the areas, we added the following two measures to these indicators: the activity index, which evaluates whether the production of a national community in a certain area is equal to, higher than, or lower than global production in this area; and the relative citation rate, which analyzes citations received by national articles compared to citations received by the area at a global level (Table IV).

For citations per document, the highest values were in the areas of Biological Sciences, Health Sciences, Earth and Exact Sciences, and Engineering. In an intermediate position were the Agricultural Sciences, Applied Social Sciences, and the Humanities. Last, Arts, Literature, and Linguistics showed the lowest value for citations per document.

The proportion of citations obtained in national journals allows us to identify the national or foreign origin of citations received. For this indicator, the lowest values were observed for Applied Social Sciences and Health Sciences, in which less than $30 \%$ of citations were obtained in national journals. In an intermediate position were the areas of Engineering, Biological Sciences, Humanities and 
TABLE IV

Selected bibliometric indicators by major area of knowledge. Brazil 2009-2010.

\begin{tabular}{c|c|c|c|c|c|c}
\hline Major Area & $\begin{array}{c}\text { Citations/ } \\
\text { Document }\end{array}$ & $\begin{array}{c}\text { \% National } \\
\text { Citations }\end{array}$ & $\begin{array}{c}\text { \% of Global } \\
\text { Production }\end{array}$ & $\begin{array}{c}\text { \% International } \\
\text { Collaboration }\end{array}$ & $\begin{array}{c}\text { Activity } \\
\text { Index* }\end{array}$ & $\begin{array}{c}\text { Relative Rate } \\
\text { of Citation** }\end{array}$ \\
\hline Biological S. & 1.3 & 36.5 & 2.6 & 28.0 & 1.1 & 0.6 \\
\hline Agricultural S. & 0.6 & 56.7 & 6.4 & 18.0 & 2.7 & 0.5 \\
\hline Health S. & 1.0 & 29.8 & 2.6 & 20.9 & 1.1 & 0.7 \\
\hline Earth and Exact S. & 0.9 & 40.3 & 1.9 & 36.2 & 0.8 & 0.7 \\
\hline Engineering & 0.9 & 34.5 & 1.4 & 26.8 & 0.6 & 0.9 \\
\hline Social S. & 0.3 & 23.7 & 1.1 & 25.5 & 0.5 & 0.5 \\
\hline Applied Social S. & 0.2 & 37.3 & 2.4 & 21.3 & 0.9 & 0.3 \\
\hline Arts, Literature, and Linguistics & 0.0 & 47.1 & 1.2 & 11.0 & 0.5 & 0.2 \\
\hline Total & 0.9 & 37.3 & 2.4 & 21.3 & 1.0 & 0.8 \\
\hline
\end{tabular}

Source: SCImago 2012 ( SJR - Journals \& Country Rank).

* Ratio between area's participation in the country's production and area's participation in global science.

** Citations received by national articles compared to citations received by the area at the global level.

Social Sciences, and Earth and Exact Sciences, with 30 to $40 \%$ of citations originating in national journals. The highest values were in the areas of Arts, Literature, and Linguistics and Agricultural Sciences, showing that a considerable portion of the production's impact occurs nationally.

The number of national journals in the Scopus database could influence the proportion of national citations. However, there was no correspondence between the values $(r=-0.21 ; p<0.01)$. The area of Applied Social Sciences had 18 national journals in the database, a number similar to the 16 journals for Earth and Exact Sciences. Health had the greatest number of national journals in the database (73) and received a lower proportion of national citations than the areas of Biological Sciences and Agricultural Sciences, which together had 59 national journals.

In the case of Agricultural Sciences, these data confirmed the predominance of Portuguese articles. In the case of Biological Sciences, the relatively high proportion of citations from national journals may be associated with the fact that the Brazilian journals with the highest impact factor (Memórias do Instituto Oswaldo Cruz) and highest $\mathrm{H}$ factor (Brazilian Journal of Medical and Biological Research) in the database are both from this area.
The relative contribution of each of the major scientific areas to global science was variable, and the highest contributions were from Agricultural Sciences and Health Sciences. At an intermediate level were Biological, Earth and Exact, and Humanities and Social Sciences. At the lower level were Engineering, Applied Social Sciences, and Arts, Literature, and Linguistics.

The activity index (ratio between the area's contribution in the country's publication and the area's contribution in global science) was only above 2.00 for Agricultural Sciences, showing the relative size of this production in Brazilian science, which far exceeded the proportion of Agricultural Sciences in global science. Health and Biological Sciences showed values slightly above 1.00, and Humanities and Social Sciences and Earth and Exact Sciences showed values slightly below 1.00 , denoting a balance between the production volume in the country and in the world. Engineering, Applied Social Sciences, and Arts, Literature, and Linguistics had less production in the country than in global production. The same indicator constructed with 2004 data using the SJR showed a different picture. At that time, a relatively higher value was noted for Natural Sciences (Biology and 
Earth and Exact Sciences) than for Agricultural Sciences. Health Sciences showed a smaller relative production, and the value was the same for Engineering (Glänzel et al. 2006).

The highest proportion of articles in collaboration with foreign researchers was observed in the area of Earth and Exact Sciences. The areas of Biological Sciences, Engineering, Applied Social Sciences, Humanities and Social Sciences, and Health Sciences evidenced values between 20 and $30 \%$. The lowest values for international collaboration were observed for Agricultural Sciences and Arts, Literature, and Linguistics.

As there are no established parameters for this indicator, we compared the national data with data corresponding to production in the United States. For all areas of knowledge, Brazilian papers showed $21.3 \%$ with international collaboration, whereas for North American science, the value was $28.5 \%$. In the United States, the area with the highest international collaboration was Earth and Exact Sciences (38.7\%), similar to the $36.2 \%$ observed in Brazil. The areas that showed the greatest discrepancies between the two countries were Biological Sciences (33\% US versus 28\% BR) and Agricultural Sciences (37\% US versus $18 \%$ BR). For the other areas, the values were similar. Humanities and Social Sciences and Arts, Literature, and Linguistics showed a higher proportion of international collaboration in Brazil than in the United States.

Considering all of the indicators shown in Table IV, the communities with the greatest scientific prestige were in Health and Biological Sciences (highest impact factor, highest international collaboration, highest activity index, smallest proportion of citations from national journals, and high rates of relative citations), followed by Earth and Exact Sciences and Engineering. Although the community of Agricultural Sciences showed the highest international sharing between the communities analyzed and, therefore, the highest activity index, it evidenced a lower gross and relative impact, greater proportion of national citations, and low international cooperation. The communities with a lower accumulation of force in this regard were the Humanities and Social Sciences, Applied Social Sciences, and Arts, Literature, and Linguistics.

SYMBOLIC CAPITAL

The symbolic capital of each scientific community can be indirectly evaluated by the paradigms and thinking styles and the social perception surrounding these paradigms. At least four major paradigms can be identified, each of which is shared by some of the major areas.

The characteristic paradigm of the Natural Sciences is one in which basic research predominates, i.e., research oriented primarily toward advancing scientific knowledge without an immediate perspective for the application of this knowledge to the solution of practical problems (Stokes 2005). The Biological Sciences and Earth and Exact Sciences share this paradigm. It is characterized by strong unity between object and method, empiricism, inductivism, testability, neutrality, and a marked separation between knowledge and common sense. Scientific knowledge is considered as a means of prediction and control of natural phenomena. There are two epistemological orientations in this paradigm: positivism and realism.

Positivist thought was rooted in English empiricism in the $18^{\text {th }}$ century and founded the knowledge on sensory data. The data were sorted by the reason to probable relationships that were subject to verification though repeated observation without certainty that the formulated laws were universal and necessary. The scientific laws are statements that express regularities observed in nature (Japiassu 1981).

Realist thought originated in Cartesian rationality in the $17^{\text {th }}$ century. It asserts the existence of a world independent from researchers' sensations 
and observations. For the realist conception of the universe, the world is constituted by phenomena that can be understood by logical reasoning. Scientific laws are also real, and scientists must discover them (Japiassu 1981).

In the $20^{\text {th }}$ century, this paradigm was reformulated to overcome dichotomies between empiricism and rationalism, induction and deduction, and verification and falsification. The so-called critical rationalism from philosophers such as Bachelard adopted the constructivist mode, in which the scientific object is built, thought, and elaborated according to a theoretical problem that allows aspects of reality that are related to the problem to be systematically studied. Scientific discourse is characterized by coherence, consistency, objectivity, and temporariness (Japiassu 1981).

The Humanities and Social Sciences and the major area of Arts, Literature, and Linguistics share a second paradigm. It is the paradigm of culture or human sciences, in contrast to the paradigm of natural sciences. In the Humanities, the subject-object relationship is circular insofar as the researcher is part of the whole that he attempts to investigate. Thus, in each particular case, it is necessary to define the level of objectivity available for the study. Social reality is simultaneously constituted by material, intellectual, and emotional facts that structure the collective and individual conscience, including that of the researchers. Thus, rigorously objective studies are impossible (Goldmann 1984). In the Humanities, the individual plays two different roles in the scientific field. On the one hand, he is part of the material things that compose the empirical world. On the other hand, he is the foundation that makes every form of knowledge possible (Machado 1982).

The knowledge of man, unlike the natural sciences, is always tied to ethics or politics and is historical, meaning that the objects of different disciplines do not escape historical movement. For the Humanities, history constitutes a common ground and defines a cultural area in which knowledge can be validated while simultaneously limiting a claim to universality (Foucault 1967). Human facts are historical, endowed with value, meaning, significance, and purpose. These characteristics distinguish them from natural factors. Thus, methods of observation and analysis that lead to explanations and understanding of meaning must be adopted (Chauí 2002).

Until the 1960s, the separation between basic and applied research was a dominant idea in the scientific and technological policy and the views of science among governments, communities of scientists, and mass media. The belief that the knowledge generated by basic science is converted into practical use through a flow from science to technology is common in the conception of technology transfer. In the second half of the $20^{\text {th }}$ century, a new paradigm was formulated that broke away from the previously linear conception and associated science, technology, and innovation with the process of societal development. The review by Manual Frascati in 1970 (Organization for Economic Cooperation and Development - OECD 2007) defined applied research as an original study undertaken to obtain new scientific knowledge and understanding. It is aimed primarily at a specific application or practical objective. In this way, the new scientific paradigm that began to be elaborated in the 1980s abandoned the division between pure and applied research and adopted a strategic research designation.

A third paradigm that focuses on strategic or applied research (Stokes 2005) is shared by Agricultural Sciences, Health Sciences, and Applied Social Sciences. The research problems refer to both producing new knowledge and demanding solutions for practical problems. This paradigm of strategic research generally combines interdisciplinarity, diverse methodology, triangulation methods, and multidisciplinary 
teams. That is, the researchers utilize resources that address the complexity of research problems that meet the challenge of advancing knowledge and offer solutions for concrete problems.

Lastly, engineers are driven by a fourth paradigm that can be called the technological paradigm, in which a commitment to developing technologies for process or product is at the heart of scientific production. Technology is scientific knowledge that is practically applied (Chauí 2002). Technological production consists of systematic studies that are based on existing or new knowledge obtained by research or practical experience. It is directed at producing new materials, products, or tools, installing new processes, systems, and services, or substantially improving existing ones (OECD 2007). The technological process shifts from a certain degree of capacity to an improved capacity through studies with welldefined targets and project improvements or by means of practical experiments. This trajectory is strongly influenced by developments in science and influences the scientific trajectory in the other paradigms (Stokes 2005).

These four paradigms correspond to the various symbolic capitals in society and within the scientific field. The paradigm with the highest level of scientific status is, without question, the paradigm of the natural sciences. The other paradigms are often not considered as distinct modalities and distinct traditions of scientific study, but as quasi-scientific knowledge that is the "immature" fruit of the other fields of knowledge.

Therefore, in terms of symbolic capital, the main areas of Biological Sciences and Earth and Exact Sciences stand out because the paradigm in which these communities work tends to be considered as more scientific by scientists and society in general. In research on the public perception of science, visions of science as a "quest for knowledge" and "mastery over nature" predominate, followed by the purpose of "solution to problems" (Fundação de Amparo à Pesquisa do Estado de São Paulo - FAPESP 2005, Ministério da Ciência e Tecnologia - MCT 2011).

POLITICAL CAPITAL

The political capital of the different communities was evaluated by the duration of presidential mandates that each area had in major agencies in the Brazilian science and technology system and in SBPC and ABC. The major areas with the highest participation in $\mathrm{S} \& \mathrm{~T}$ policy leadership in the country, whether in the government or in scientific communities, were Health Sciences and Earth and Exact Sciences, with 32\% and 30\%, respectively. Engineering held $11 \%$ of the duration of presidential mandates, and Biological Sciences held $10 \%$. Next, the Humanities and Social Sciences and the Applied Social Sciences held 7\% and $9 \%$, respectively, of the duration of mandates. Agricultural Sciences held approximately $1 \%$ of the duration of mandates. Lastly, Arts, Literature, and Linguistics never had a member as chairman of the agencies considered.

Earth and Exact Sciences stands out among the leaders of the three federal agencies, CAPES, CNPq, and FINEP, and the scientific societies. The representatives from Engineering primarily led FINEP and CNPq. Researchers in Health Sciences stand out among the presidents of CNPq, SBPC and ABC. The communities of Humanities and Social Sciences and Applied Social Sciences stand out in the presidency of CAPES.

Therefore, the areas of Engineering, Earth and Exact Sciences, and Health Sciences had the greatest accumulation of political capital. For the latter two areas, the political capital position corresponded to the position observed for structural composition, social capital, and symbolic capital. However, for Engineering, political capital was much higher than would be expected given its structural composition and social and symbolic capital. The small participation of researchers from Biological 
Sciences in directing agencies calls attention, as it is much lower than its structural composition and social and symbolic capital would lead us to expect.

\section{ECONOMIC CAPITAL}

As a proxy for each scientific community's economic capital, we considered the proportion of permanent faculty members in graduate programs with research productivity grants and the amount of funding for research projects from CNPq. (Table V) The two measures were correlated ( $\mathrm{r}=$ $0.95 ; \mathrm{p}<0.01)$. Table $\mathrm{V}$ presents the funding from FINEP for R \& D in each major area.

The three major areas with the highest economic capital were Biological Sciences, Agricultural Sciences, and Earth and Exact Sciences. It is noteworthy that Health Sciences demonstrated lower economic capital.

TABLE V

Research productivity grants and percentage of funding resources (grants and projects) received from CNPq and FINEP. Brazil 2011.

\begin{tabular}{c|c|c|c}
\hline Major Area & $\begin{array}{c}\text { Productivity Grants/Faculty Members } \\
\text { from Graduate Programs (\%) }\end{array}$ & $\begin{array}{c}\text { CNPq Funding } \\
(\mathbf{\%})\end{array}$ & $\begin{array}{c}\text { FINEP Funding } \\
(\mathbf{\%})\end{array}$ \\
\hline Biological S. & 68.2 & 22.2 & 7.8 \\
\hline Agricultural S. & 52.8 & 16.1 & 12.6 \\
\hline Health S. & 26.4 & 10.6 & 6.3 \\
\hline Earth and Exact S. & 56.1 & 17.5 & 3.2 \\
\hline Engineering & 42.2 & 15.9 & 63.9 \\
\hline Social S. & 27.2 & 12.2 & 0.1 \\
\hline Applied Social S. & 19.7 & 3.8 & 6.0 \\
\hline $\begin{array}{c}\text { Arts, Literature } \\
\text { and Linguistics }\end{array}$ & 10.0 & 1.8 & 0.1 \\
\hline Total & $\mathbf{3 1 . 7}$ & $\mathbf{1 0 0 . 0}$ & $\mathbf{1 0 0 . 0}$ \\
\hline
\end{tabular}

Source: CNPq 2011, 2012 (Active productivity grants and Databank and Statistics); FINEP 2011. (Contracted projects).

* Percentage of permanent teachers in graduate programs with productivity grants from CNPq and FINEP.

In general, the distribution of economic capital followed the structural capacity of each scientific community $(r=0.86 ; p<0.05)$, with the exception of Health, which was exceeded by Agricultural Sciences, Engineering, and Humanities and Social Sciences.

Funding from FINEP refers almost exclusively to $\mathrm{R} \& \mathrm{D}$, with most projects developed by companies. The results showed a different profile, with greater predominance for Engineering and Agricultural Sciences and less weight for Earth and Exact Sciences. This markedly asymmetric distribution reflects the recent trend in national science and technology policy (Mota 2010).

Therefore, in terms of economic capital, the scientific and technological communities with the greatest power and accumulation of strength were in Biological Sciences, Agricultural Sciences, Earth and Exact Sciences, and Engineering. This profile indicates a model in which the natural sciences and applied or technological areas with greater economic relevance for the country receive more support. The applied areas related to social policies and the area of Humanities receive less priority.

Health Sciences received a greater impetus in terms of funding, with the creation of the Departamento de Ciência, Tecnologia e Inovação - DECIT in the Ministry of Health in 2003. In 2010, around \$R 23 million were directly invested into health research, which included studies in biomedical sciences, clinical studies, and public health. This value excludes the \$R 20 million transferred by the Ministry of Health to CNPq. In 2010, funding from DECIT represented 14\% of funding from $\mathrm{CNPq}$ for the area of Health and 
$1.5 \%$ of the agency's total funding. Therefore, although Health Sciences received sectoral support, funding for its scientific community remained below that for Biological Sciences, Earth and Exact Sciences, Agricultural Sciences, and Engineering.

\section{SCIENTIFIC FIELD, COMMUNITIES, AND DifFERENT TyPES OF CAPITAL}

The analysis of the communities that compose the Brazilian scientific field began from the premise that scientific production in each community depends on installed capacity and the capacity to train new practitioners and that both, in turn, determine the structural configuration of each community. For operational reasons, the analysis was conducted at a high level of aggregation: practitioners grouped into major areas of knowledge form each community. There is great heterogeneity within each of these communities, both for the communities in each discipline or field of knowledge and between the different groups of specialists within each discipline. For example, the area of Earth and Exact Sciences consists of five disciplines, Astronomy and Physics, Chemistry, Mathematics and Statistics, Computer Sciences, and Geosciences. Although these disciplines have common features that can be differentiated from disciplinary fields in other areas, there is much heterogeneity between them.

The area of Physics, for example, following the tree of knowledge adopted by funding agencies in Brazil, has sub-areas such as atomic and molecular physics, condensed matter physics, elementary particle physics, physics of fluids, plasma, and electric discharges, nuclear physics, and general physics. Each sub-area includes different thought collectives or schools of thought.

Another important limitation of this study is that the databases organize information according to different classification categories, often making it difficult to regroup the categories to make them comparable.
Considering installed capacity, capacity of training new researchers, and academic production as the structural components of each community, the noteworthy areas were Biological Sciences, Earth and Exact Sciences, Health Sciences, and Agricultural Sciences.

Supposedly, this structural configuration should correspond to different capitals with which scientists established their positions of power within the scientific field. These capitals confer their respective communities advantages or disadvantages, whether in competition for financial resources or in competition for recognition or social prestige.

In addition to the structural components, this configuration of fields of strength between different communities is likely influenced by each scientific community's symbolic capital. This capital is related to the paradigms of scientific production shared by practitioners and to the symbolic value that these paradigms acquire for society in general.

In symbolic terms, the communities in Biological Sciences, Earth Sciences, Agricultural Sciences, and Health Sciences have the greatest accumulation of strength insofar as they share paradigms that the general public and scientists tend to consider as carrying the greatest scientific value. Therefore, symbolic capital seems to accompany structural characteristics, conferring more power to the communities with greater structural densities.

The social capital or prestige of the communities in terms of their visibility and impact on the national and international scientific community corresponds to a different distribution of power. The community of Agricultural Sciences, given its predominantly national expression, has lower capital than the community of Engineering. In comparison, Biological Sciences, Earth and Exact Sciences, and Health Sciences demonstrate a greater accumulation of capital. The community of Health Sciences, which is internally more heterogeneous than the other areas, loses some of its power insofar 
as it contains areas with great scientific prestige such as medicine and areas with less prestige such as physical therapy, speech therapy, occupational therapy, and physical education.

Political capital does not correspond to the structural composition or social and symbolic capital, except for the areas of Earth and Exact Sciences and Health Sciences. Engineering shows similar political power to Biological Sciences, although it has less scientific and symbolic prestige. The distribution of economic capital, however, demonstrates a new twist, excluding the community of Health Sciences and including Agricultural Sciences among the best.

Although concern for health is predominant in society in general, this does not translate into governmental priority for Health Sciences. From a more utilitarian perspective, governmental priority has favored Agricultural Sciences, whose economic relevance for the country is undeniable. More recently, it has favored Engineering, seeking to prioritize innovation as a means of overcoming imbalances in foreign trade and a critical element in national development.

Health and other areas of social policies have not been given priority in the scientific and technological field with respect to sources and amounts of funding. The utilitarian perspective cannot explain why the areas of Biological and Earth and Exact Sciences continue to receive higher priority, even though a growing part of research in these fields has been strategic research.

Finally, under all of the views considered here, the Applied Social Sciences, Humanities and Social Sciences, and Arts, Literature, and Linguistics show the lowest accumulation of capitals. This finding does not indicate a lower level of scientific value or social relevance of these communities. Rather, these findings demonstrate that the resources at stake in the scientific field are appropriated by other communities to a greater extent, leaving the humanities researchers in a situation with less power to fight for financial resources, recognition, and prestige.
In addition to the size of different types of capital, the positions in the social space that constitutes the scientific field are also defined by the composition between the capitals accumulated by the scientific communities, which are then configured as political agents. The community of Biological Sciences has higher economic, social, and symbolic capital; therefore, it holds the position with the most power within the field. Engineering has high economic capital and intermediate social and symbolic capital and, thus, power. The Earth and Exact Sciences community has high symbolic capital and intermediate social and economic capital, standing on nearly equal terms with Engineering. These three communities have accumulated the greatest power in the country's scientific field.

A second power cluster includes Agricultural Sciences, which has intermediate economic and symbolic capital and low social capital, and Health Sciences, with high social capital, intermediate symbolic capital, and low economic capital. The third cluster, with even smaller forces, includes the remaining three communities, as follows: Applied Social Sciences, with intermediate symbolic capital and low economic and social capital; Humanities and Social Sciences and Arts, Literature, and Linguistics, both with low symbolic, economic, and social capital.

The political field is where the problems, programs, events, reviews, and political products are generated through competition between agents. That is, scientific policy is produced from the relationships that are established between the actors within the field and actors in other social sectors.

Competition within the field produces a specific form of interest that is geared toward winning a monopoly of scientific authority, in which technical competence and symbolic power are confused. The fight within the scientific field is developed under the control of standards for scientific practice; thus, it only draws from authorized resources.

Within the broader social area, or outside the limits of the field itself, scientific explanations 
about the world must be affirmed against other explanations or forms of knowledge while drawing on the social strength of scientists and symbolic effectiveness of their rhetorical strategies. The social position of scientists in general, and of various communities in particular, is constructed in the process of distinction that is established between this particular group of agents and other agents. The habitus of scientists, acquired in the stages of training and professional activities, provides science practitioners layouts of experience-perception-action that form a basis for an implicit collusion between them. Each scientist finds ratification and legitimacy of his conduct in the conduct of his peers.

Social recognition makes these communities of scientists visible, celebrated, admired, quoted, invited, etc. This recognition provides the privilege of being known/recognized. The scientists have the power to know/recognize, declare what deserves to be known, and label what is known and in what it consists.

Each scientific community with power acquired through accumulating different types of capital seeks to occupy social areas within the scientific field and the broader social arena, where there are different rules of the game and the effective distinction mechanisms within the field may not apply.

\section{RESUMO}

O artigo descreve a configuração do campo científico no Brasil caracterizando as comunidades científicas em cada grande área do conhecimento em termos de sua capacidade instalada, capacidade de formação de novos pesquisadores e capacidade de produção acadêmica. São utilizados dados empíricos de diferentes fontes de informação para a caracterização das diferentes comunidades. Articulando as contribuições teóricas de Pierre Bourdieu, Ludwik Fleck e Thomas Kuhn são analisados os seguintes tipos de capital de cada comunidade: capital social (prestígio científico), capital simbólico (paradigma dominante), capital político (liderança na política de C\&T) e capital econômico (recursos). O prestígio científico é analisado levando em conta o volume de produção, o índice de atividade, as citações e outros indicadores. Para a caracterização do capital simbólico são analisados teoricamente os paradigmas dominantes que distinguem as ciências naturais, as humanidades, as ciências aplicadas e o desenvolvimento da tecnologia. O capital político é medido pela presidência por uma das principais agências do sistema nacional de C\&T e o capital econômico é determinado pelos recursos para pesquisa e concessão de bolsas. $\mathrm{O}$ artigo discute a composição destes diferentes tipos de capitais bem como suas correspondências com as capacidades estruturantes das diversas comunidades visando descrever a configuração do campo científico brasileiro.

Palavras-chave: comunidade científica, campo científico, ciência brasileira, capital científico.

\section{REFERENCES}

Almeida Filho NO. 2011. O que é saúde? Editora Fiocruz, Rio de Janeiro.

Bourdieu P. 2001. Meditações Pascalinas. Editora Bertrand Brasil, Rio de Janeiro.

BouRdieu P. 1989. O Poder Simbólico. Editora Bertrand Brasil, Rio de Janeiro.

CAPES. 2011a. Recommended Courses. Study in October. http://capes.gov.br

CAPES. 2011b. Geocapes. Statistical Data. Study in October http://capes.gov.br

Chauí M. 2002. Convite à Filosofia. Editora Ática, São Paulo.

CNPq. 2010. Directory of Research Groups. Census. Study in October. http://www.cnpq.br

CNPq. 2011. Active Productivity Grants. Study in October. http://www.cnpq.br

CNPq. 2012. Databank and Statistics. Study in January. http://www.cnpq.br

ETXEBARRIA G AND GOMEZ-URANGA M. 2010. Use of Scopus and Google Scholar to measure social sciences production in four major Spanish universities. Scientometrics 82: 333-349.

FAPESP. 2005. Indicators of Science, Technology, and Innovation. Chapter 12: Public perception of science: a methodological review and results for São Paulo. São Paulo.

FINEP. 2011. Contracted Projects. Http://www.finep.gov.br (accessed on 08/06/2012).

FLECK L. 1986. La Genesis y El desarrollo de un hecho científico. Alianza Editorial, Madrid.

Foucault M. 1967. As Palavras e as Coisas. Livraria Martins Fontes Editora, São Paulo.

GARCIA JR A. 2011. Mobilité universitaire et circulation internationale dês idees. Le cas du Brésil contemporain. Revue de synthèse 132(4): 567-574. 
GLÄNZEL W, LETA J AND ThisS B. 2006. Science in Brazil. Part 1. A macro-level comparative study. Scientometrics 67(1): 67-86.

GoldMANN L. 1984. Epistemologia e filosofia política. Editorial Presença, Lisboa.

Hermes-Lima M, Polcheira C, Trigueiro M and Beleboni RO. 2008. Perceptions of Latin America scientists about science and post-graduate education: introduction to the $5^{\text {th }}$ issue of CBP-Latin America. Comparative Biochemistry and Physiology. Part A 151: 263-271.

JAPIASSU H. 1981. Questões Epistemológicas. Editora Imago, Rio de Janeiro.

KING C. 2009. Brazilian Science on the Rise. Sciencewatch. com. Thomson Reuters. July/August.

KuHn T. 1989. A Estrutura das Revoluções Científicas. Editora Perspectiva, São Paulo.

LEAHEY E. 2007. Not by productivity alone: how visibility and specialization contribute to academic earnings. Am Sociol Rev 72: 533-561.

Leite P, Mugnani R And Leta J. 2011. A new indicator for international visibility: exploring Brazilian scientific community. Scientometrics 88: 311-319.

LETA J, GLÄNZEL W AND ThIJS B. 2006. Science in Brazil. Part 2. Sectoral and institutional research profiles. Scientometrics 67(1): 87-105.
Machado R. 1982. Ciência e Saber. As trajetórias da Arqueologia de Foucault. Editora Graal, Rio de Janeiro.

MCT. 2011. Percepção pública da ciência e tecnologia no Brasil. Brasília.

MotA R. 2010. Inovação na Sociedade e as Ciências Básicas na $4^{\mathrm{a}}$ CNCTI- Conferência Nacional de Ciência, Tecnologia e Inovação. Editorial. J Braz Chem Soc 21(4): 573.

OECD. 2007. Manual de Frascati. Proposta de práticas exemplares para inquéritos sobre investigação e desenvolvimento experimental. Coimbra.

REGALAdO A. 2010. Brazilian science riding a gusher. Science 330: 1306-1312. (3 December).

SCIMAGO. 2012. SJR - Journals \& Country Rank. Retrieved March 02 2012. http://www.scimagosjr.com

STOKEs DE. 2005. O Quadrante de Pasteur. A Ciência Básica e a Inovação Tecnológica. Editora da UNICAMP, Campinas.

VASCONCELOS SMR, SORENSON MM AND LETA J. 2008. Researcher's writing-competence: a bottleneck in the publication of Latin-American science? EMBO Reports 9(8): 700-702. 